\title{
Social Networking and Academic Adjustment of English Language Students
}

\author{
Josphine U. Akabogu ${ }^{1}$, Kizito C. Ibe ${ }^{2}$, Joachim C. Omeje ${ }^{2}$, Moses O. Ede ${ }^{2 *}$, \\ Alexander C. Ezurike ${ }^{2}$, Eucharia N. Ezeh ${ }^{2}$, Amuche P. Nnamani ${ }^{1}$ \\ and Ann. C. Ulo-bethels ${ }^{1}$ \\ ${ }^{1}$ Department of Arts Education, Faculty of Education, University of Nigeria, \\ Nsukka, Enugu State, Nigeria \\ ${ }^{2}$ Department of Educational Foundations, Faculty of Education, University of \\ Nigeria, Nsukka, Enugu State, Nigeria \\ 2*moses.ede@unn.edu.ng
}

\begin{abstract}
This ex-post facto research study determined the influence of social networking on academic adjustment of English Language students. 607 English Language students were used as sample size. The instrument for data collection was Social Networking and Academic Adjustment of Adolescents Questionnaire (SNAAAQ). The data collected was analyzed using mean, standard deviation and t-test. Results showed that social networking influences male and female, urban and rural English Language students' academic adjustment. It indicated that there is no significant difference between the mean ratings of English Language students from urban and rural, male and female areas on the influence of social networking academic adjustment. We recommend that language experts, counsellors and researchers should conduct a randomized control trial to evaluate the effect of social networking on academic adjustment of English Language students.
\end{abstract}

Keywords: Social networking, Academic adjustment, English Language students

\section{Introduction}

The world is speedily growing technologically. The trend appeared to have influenced life style of many people. That is why students and organization are shifting to digitalization (Omekwu, Eke and Odoh, 2014). Presently, activities of man such as education and communication have continued to incorporate the new wave. One of the technological innovations is social networking. Social networking is a platform where people communicate to one or more individuals through the services of internet resources. This implies that networking is a way of reaching out to other people. Social networking is therefore a means of communication through which tools like wall posts, status updates, activity feeds, thumbs ups and profiles are used and perhaps characterized online communication namely facebook, Myspace Metlog, Fliker and Twitter (Akaneme, Ibenegbu and Nwosu, 2013).

Social networking enhances the possibilities for communicating with wider people. Literature showed that many people (mostly students) use it for their academic and commercial activities. Because of that, it has recorded unprecedented popularity in the globe (Awake, 2011; Omekwu, Eke and Odoh, 2014). Earlier study reported that it took media about four decades to connect the users but social network reach about 200 million

Received (January 10, 2018), Review Result (March 7, 2018), Accepted (March 13, 2018)

${ }^{*}$ Corresponding Author 
users in a year (Omekwu, Eke and Odoh, 2014). Other evidence reported that about $80 \%$ of youngsters are active social networking users (Lenhart, Madden, Smith, Purcell, Zickuhr and Rainie, 2011; Ojo and Omoyemju, 2008). The popularity of social networking appears to have become more predominantly among schooling students (Ellison, Stein field and Lampe, 2007; Miah, Omar and Golding, 2012).

However, one could assume that social networking increases the possibilities for developing social relationships. This agrees with the basic assumption of social theory of Albert Bandura that individuals learn new behavior via watching and imitating (Bandura, 1986). We assume that English Language students watch what is obtainable in the environment and copy them. Even with digitalization they may be in the remotest part of Nigeria and still imitate who so ever they want to imitate through the use of social networking. In essence, social networking serves as social capital that could helps adolescents to develop socially and intellectually.

On the view of impacts of social networking on cognitive development of students, Mason (2006) argued that social networking sites have enough competence for a good 'official' education matching the social background of learning and promoting ability to think in learning. Social networking helps students to build a stronger social skill and use it to improve academic performance. Social networking as a new development has been described as a stage for facilitation and development of in-schools adolescents' social adjustment (Subrahmanyam and Green-field, 2008; Zhao, Grasmuck and Martin, 2008). Social networking has the tendency to influence educational system and motivates students for better learning rather than being inactive students in classroom (Ziegler, 2007). It is expected primarily that social networking could give opportunity to students to accomplish online many academic tasks that are significant to them which could not get done offline (Akaneme, Ibenegbu and Nwosu, 2013).

Reiterating on the importance of social networking to adolescents, Idankwo (2011) found that when students engage in social networking, they are motivated and goal oriented to preserve their self-confidence. So, social networking helps in establishing relationship with people, friends and relatives, and through that they share views, pictures and lots of other stuffs.

Studies have indicated that in recent times, about $90 \%$ of youths worldwide consider social networking so important regardless of its adverse effect on their academic pursuit (Akaneme, Ibenegbu, and Nwosu; 2013, Awad, 2013; Bosch, 2009, Miah, Omar and Golding, 2012). Evidence reported that about $80 \%$ of youngsters are active social networking users (Lenhart, Madden, Smith, Purcell, Zickuhr and Rainie, 2011). Contrary to the above positive impacts, social media makes Nigerian youths to waste valuable time and provide them derailed information like phone numbers, addresses that are very dangerous because they can easily be tracked down by stranger. Also it exposes them to international fraudsters (Kumuyi, 2015). With the negative impacts in mind, guidance counselors, teachers and other significant figures are charged with the responsibility of watching them closely. The widespread of social networks has generated concerns form researchers, organizations, and government (Musa, 2015). The concerns seem to be hinged on the far reaching negative impacts of social networking on students.

Furthermore, Akaneme, Ibenegbu and Nwosu (2013) found that Nigerian students use of social networking have undue influence on their academic achievement. The widespread of social networking has made students to spend much of their valuable time chatting online (Baker and White, 2010). Studies have shown that students' online presentation is a reflective of their offline world (Back, Stopfer, Vazire, Gaddis, Schmukle, Eglott and Gosling, 2010; Moreno, Christrakis, Egan, Jelenchick, Ox, Young and Ba1ckers, 2011; Wright and Li, (2011).

Considerable empirical-based studies decried the rapidly increasing negative impacts of social networking on Nigerian students (English Language students inclusive) academic outcome and adjustment (Akaneme, Ibenegbu and Nwosu, 2013; Awad, 2013; 
Miah, Omar and Golding, 2012; Ojo and Omoyemiju, 2008; Omekwu, Eke and Odoh, 2014; Sani and Bature, 2014). This seems to be manifesting on the valuable time they invest in social networking (Ojo and Omoyemiju, 2008). Instead of using social networking to improve their language competence like writing skill, they have turn down the purported advantages. The negative impact has also manifested on Nigerian students' social relationships and this has posed worry to their family members (Boyd, 2009). It is daunting that the English Language students are mostly on online at the expense of their academic pursuit (Kuss and Griffiths, 2011). Invariably, Idakwo (2011) lamented that homework, examination (internal and external), and school activities are grossly affected by uncontrollable impulse among Nigerian students towards social networking. All these constituted source of worry to the present researchers, since our youngsters seems to have derailed from envisaged benefits of social networking.

The remarkable shift social media via technology has contributed to the life of people especially in the manner students interact with themselves has both positive and negative impacts on them as posited by researchers. It is therefore, important to know the possible influence social networking have on academic adjustment of English Language students.

English Language students are expected to acquire certain skills of language. Among the skills is writing (Sani and Bature, 2014). Writing skill is a primary means of communication and it provides indispensible methods of communication. English Language students apparently acquire writing skills through social networking sites which they might have missed under formal instruction (Sani and Bature, 2014). The topical development of social networks has pervasively increase students access to interact with peers via electronic messages. The Grabe and Kaplan (1996) remarked that communicative competence is linked to writing skills. It includes writing processes which start in memory where the related knowledge creates the essential information for writing. Prior study indicated high proportion English Language students use social networks for education based reasons, while $45 \%$ of students use social websites for class work, with English being the subject most studied (Miah and Omar, 2012). Eren (2012) revealed that facebook is a useful tool for mastering English language proficiency. In spite the considerable profile of studies on the influence of social networking on English Language students, still few studies have focused on the impacts of social networking in developing ESL students' academic adjustment developing regions like Nigeria (Sani and Bature, 2014).

It is a normal phenomenon that people try to maintain a good equilibrium between their internal and external demands. The same thing applies to school environment where students are poised to adapt to the school or academic demands. Every institution has a certain demand from her students for them to study which could be unacceptable to the psychological and physiological state of the students and as such require harmonization/adjustment.

Researchers have perceived that relationship exists among academic adjustment, social networking and academic pursuit. Academic adjustment is a veritable predictor of psychosocial adaptation because new experiences are learned in social milieu (Gurubasappa, 2009; Phinne, Horenczyk, Liabkind and Vedder, 2001). It was found that social media has positive impacts on positive academic success (Kao and Tienida, 1995). However, the influence of social networking on academic adjustment of English Language students in Enugu State, Nigeria is still uncertain to the researchers. Based on the background of the problem, the aim of the current study is to ascertain the influence of social networking on academic adjustment of English Language students in Enugu State, Nigeria. 


\section{Methodology}

\subsection{Design of the Study}

The researchers employed ex-post-facto research design. Nworgu (2006) noted that expost facto is a study design used where an event has occurred and no opportunity for manipulation. The choice of this design is to enable the researcher to link already existing variable (social networking) with adolescents' academic adjustment. This design enabled the researchers to investigate the influence of independent variable (social networking) on dependent variables (academic adjustment).

\subsection{Population of the Study}

The study population consists of all the 32396 students in public secondary schools in Enugu Education Zone of Enugu State, Nigeria which include 13681 students in Enugu East, 13319 in Enugu North and 5366 in Isi-Uzo. The study sample was 607 students. Multi-stage sampling technique was adopted and it involved using purposive sampling technique to select six secondary schools each from Enugu-East, Enugu-North and IsiUzo Local Government Areas (LGAs) respectively, amounting to 18 secondary schools. Also, a proportionate sampling technique (20\% of each SSII class) was used for selection of 273 male and 334 females SSII students. Also, simple random sampling balloting without replacement was used to select 6 rural and 6 urban schools from each of the LGAs.

\subsection{Instrument for Data Collection}

Social Networking and Academic Adjustment of Adolescents Questionnaire (SNAAAQ): The SNAAAQ has demographic information (gender and location). It is a 20-items questionnaire measuring the influence of social networking on academic adjustment of adolescents based on gender and location. The SNAAAQ has four ratings of Strongly Agree (SA) - 4 points to Strongly Disagree (SD) -1 point. The SNAAAQ was face validated by three experts. The SNAAAQ has the internal reliability consistency of 0.80 alpha.

\subsubsection{Method of Data Collection and Data Analysis}

The researchers distributed 476 copies of questionnaire with aid of two trained research assistants. Data collected was analyzed using mean, standard deviation, and t-test statistic. The null hypotheses were tested at 0.05 probability level. A mean value of 2.50 was used as benchmark. Therefore, any value that is 2.50 and above was accepted and any mean value that is below 2.50 was rejected.

\section{Table 1. Mean and Standard Deviation Analysis of the Influence of Social Networking on Academic Adjustment of Male and Female English Language Students}

\begin{tabular}{|c|c|c|c|c|c|c|c|}
\hline \multirow[t]{2}{*}{$\begin{array}{l}\mathbf{S} / \\
\mathbf{N}\end{array}$} & \multirow[t]{2}{*}{$\begin{array}{l}\text { Influence of Social Networking on Academic } \\
\text { Adjustment }\end{array}$} & \multicolumn{3}{|c|}{ Male : $n=267$} & \multicolumn{2}{|c|}{$\begin{array}{l}\text { Female: } \\
340\end{array}$} & \multirow{2}{*}{$\begin{array}{l}\mathbf{n}= \\
\mathbf{R} \\
\mathbf{M} \\
\mathbf{K}\end{array}$} \\
\hline & & $\bar{X}$ & SD & $\begin{array}{l}\mathbf{R} \\
\mathbf{M} \\
\mathbf{K}\end{array}$ & $\bar{X}$ & SD & \\
\hline 1. & I communicate easily with my classmates through & 2.7 & 1.0 & A & 2.8 & 1.0 & A \\
\hline & twitter messaging & 5 & 5 & & 0 & 2 & \\
\hline 2 & $\begin{array}{l}\text { Frequent facebook usage makes a student to have } \\
\text { low academic grade }\end{array}$ & $\begin{array}{l}3.1 \\
5\end{array}$ & $\begin{array}{l}0.8 \\
7\end{array}$ & A & $\begin{array}{l}3.2 \\
5\end{array}$ & $\begin{array}{l}0.8 \\
5\end{array}$ & A \\
\hline 3. & The use of twitter makes me to be vulnerable to & 2.8 & 0.9 & A & 3.8 & 1.0 & A \\
\hline
\end{tabular}


examination malpractice

$\begin{array}{llll}5 & 7 & 4 & 2\end{array}$

4. Facebook makes me to have academic peer- $3.2 \quad 0.8$ A 3.20 .8 A review together

$\begin{array}{llll}2 & 1 & 9 & 1\end{array}$

5. I spend very much time on twitter and rarely do $\begin{array}{llllll}3.2 & 0.7 & \text { A } & 3.2 & 0.7 & \text { A }\end{array}$ nothing at all for hours on my academic work $\quad \begin{array}{lllll}5 & 9 & 2 & 9\end{array}$

6. Online chatting makes me to develop my $3.3 \quad 0.7$ A $3.2 \quad 0.8$ A vocabulary

7. Facebook motivates students for better learning $3.2 \quad 0.8$ A $3.2 \quad 0.8$ A $\begin{array}{llllll}\text { rather than being passive attendees of a classroom } & 5 & 2 & 2 & 3\end{array}$

8. Twitter motivate students to be more $3.1 \quad 0.8$ A $3.0 \quad 0.9 \quad \mathrm{~A}$ $\begin{array}{llllll}\text { educationally productive } & 4 & 7 & 1 & 5\end{array}$

9. Twitter online chat promotes someone to develop $\begin{array}{lllllll}3.2 & 0.9 & \text { A } & 3.2 & 0.8 & \text { A }\end{array}$ $\begin{array}{llllll}\text { critical thinking in his or her study } & 1 & 2 & 2 & 9\end{array}$

10. Facebook is a technological tool which nurtures $\begin{array}{llllll}3.2 & 0.9 & \text { A } & 3.1 & 0.8 & \text { A }\end{array}$ $\begin{array}{llllll}\text { the student- teacher relationships } & 2 & 2 & 3 & 3\end{array}$

11. Facebook creates positive learning experiences $\begin{array}{lllllll}3.3 & 0.7 & \text { A } & 3.2 & 0.8 & \text { A }\end{array}$ $\begin{array}{lllllll}\text { for learners } & 9 & 7 & 5 & 5\end{array}$

12. Facebook updates me on current educational $3.3 \quad 0.3 \quad$ A $3.2 \quad 0.8$ A $\begin{array}{lllllll}\text { affairs } & 0 & 2 & 6 & 5\end{array}$

13. Facebook activity seduces me erotically which is $\begin{array}{llllll}3.2 & 0.7 & \text { A } & 3.1 & 0.8 & \text { A }\end{array}$ $\begin{array}{llllll}\text { affecting my academic performance } & 4 & 9 & 8 & 8\end{array}$

14. Using twitter does not make me to feel outgoing $\begin{array}{lllllll}3.0 & 0.8 & \mathrm{~A} & 3.2 & 0.8 & \mathrm{~A}\end{array}$ on issues regarding academics

$\begin{array}{llll}7 & 9 & 1 & 7\end{array}$

15. Facebook motivates me to express my academic $\begin{array}{lllllll}3.2 & 0.7 & \text { A } & 3.2 & 0.8 & \text { A }\end{array}$ problems

$\begin{array}{llll}8 & 9 & 3 & 4\end{array}$

16. Twitter activity makes me feel less depressed $3.2 \quad 0.7$ A $\begin{array}{llllll}3.1 & 0.8 & \text { A }\end{array}$ $\begin{array}{llllll}\text { each time examination is approaching } & 1 & 2 & 6 & 0\end{array}$

17. Facebook helps me to connect with students who $\begin{array}{llllll}3.2 & 0.8 & \text { A } & 3.0 & 0.9 & \text { A }\end{array}$ $\begin{array}{llllll}\text { share similar academic problem } & 2 & 4 & 6 & 9\end{array}$

18. Facebok helps me to express my academic $3.1 \quad 0.7$ A $3.1 \quad 0.8$ A $\begin{array}{llllll}\text { challenges to my school counsellor privately } & 9 & 9 & 8 & 4\end{array}$

19. I am usually withdrawn from academic work due $\begin{array}{lllllll}3.1 & 0.7 & \mathrm{~A} & 3.1 & 0.8 & \mathrm{~A}\end{array}$ $\begin{array}{llllll}\text { to whatapp addiction } & 1 & 3 & 2 & 6\end{array}$

20. Twitter introduced me to an elevated risk of drug $\begin{array}{lllllll}3.0 & 0.9 & \text { A } & 3.1 & 0.9 & \text { A }\end{array}$ $\begin{array}{lllllll}\text { use which is affecting my academic pursuit now. } & 1 & 6 & 2 & 3\end{array}$

\section{Cluster Mean and standard Deviation \\ $\begin{array}{llllll}3.1 & 0.4 & \text { A } & 3.1 & 0.4 & \text { A }\end{array}$}

$\begin{array}{llll}7 & 7 & 5 & 7\end{array}$

Criterion Mean $(\bar{X})=2.50 ; \mathrm{SD}=$ Standard Deviation; A = Agree

Table 1 shows mean and standard deviation analysis of the influence of social networking on academic adjustment of male and female English Language students. The analysis shows that mean score ratings of male and female English Language students to items 1 to 20 are more than 2.50 bench mark mean. In addition, the mean score ratings of items 2,3,5,13,19, and 20 for both male and female English Language students indicate the negative influence of social networking. Although, items 1, 4, 6, 7, 8, 9, 10, 11, 12, $14,15,16,17$, and 18 reveal the positive influence of social networking. This implies that social networking influences male and female in-school adolescents' academic adjustment. Furthermore, the overall standard deviation of both male and female English Language students do not have any veracity. This implies that less disparity exists between male and female English Language students on the influence of social networking. 
Table 2. Mean and Standard Deviation Analysis of the Influence of Social Networking on Academic Adjustment of Urban and Rural English Language Students

\begin{tabular}{|c|c|c|c|c|c|c|c|}
\hline \multirow[t]{2}{*}{$\mathbf{S} / \mathbf{N}$} & \multirow{2}{*}{$\begin{array}{l}\text { Influence of Social Networking on Academic } \\
\text { Adjustment }\end{array}$} & \multicolumn{3}{|c|}{ Rural : $n=121$} & \multicolumn{3}{|c|}{ Urban : $n=486$} \\
\hline & & $\bar{X}$ & SD & $\begin{array}{l}\mathbf{R} \\
\mathbf{M} \\
\mathbf{K}\end{array}$ & $\bar{X}$ & SD & $\begin{array}{l}\mathbf{R} \\
\mathbf{M} \\
\mathbf{K}\end{array}$ \\
\hline 1. & $\begin{array}{l}\text { I communicate easily with my classmates through } \\
\text { twitter messaging }\end{array}$ & $\begin{array}{l}2.8 \\
4\end{array}$ & 1.08 & $\mathrm{~A}$ & $\begin{array}{l}2.7 \\
6\end{array}$ & $\begin{array}{l}1.0 \\
2\end{array}$ & A \\
\hline 2. & $\begin{array}{l}\text { Frequent facebook usage makes a student to have } \\
\text { low academic grade }\end{array}$ & $\begin{array}{l}3.1 \\
7\end{array}$ & 0.93 & A & $\begin{array}{l}3.2 \\
1\end{array}$ & $\begin{array}{l}0.8 \\
4\end{array}$ & A \\
\hline 3. & $\begin{array}{l}\text { The use of twitter makes me to be vulnerable to } \\
\text { examination malpractice }\end{array}$ & $\begin{array}{l}2.7 \\
9\end{array}$ & 0.98 & A & $\begin{array}{l}2.8 \\
7\end{array}$ & $\begin{array}{l}1.0 \\
0\end{array}$ & A \\
\hline 4. & $\begin{array}{l}\text { Facebook makes me to have academic peer-review } \\
\text { together }\end{array}$ & $\begin{array}{l}3.1 \\
5\end{array}$ & 0.83 & A & $\begin{array}{l}3.2 \\
8\end{array}$ & $\begin{array}{l}0.8 \\
0\end{array}$ & A \\
\hline 5. & $\begin{array}{l}\text { I spend very much time on twitter and rarely do } \\
\text { nothing at all for hours on my academic work }\end{array}$ & $\begin{array}{l}3.3 \\
4\end{array}$ & 0.75 & A & $\begin{array}{l}3.2 \\
1\end{array}$ & $\begin{array}{l}0.7 \\
9\end{array}$ & A \\
\hline 6. & $\begin{array}{l}\text { Online chatting makes me to develop my } \\
\text { vocabulary }\end{array}$ & $\begin{array}{l}3.1 \\
8\end{array}$ & 0.75 & A & $\begin{array}{l}3.3 \\
1\end{array}$ & $\begin{array}{l}0.7 \\
9\end{array}$ & A \\
\hline 7. & $\begin{array}{l}\text { Facebook motivates students for better learning } \\
\text { rather than being passive attendees of a classroom }\end{array}$ & $\begin{array}{l}3.2 \\
7\end{array}$ & 0.84 & A & $\begin{array}{l}3.2 \\
2\end{array}$ & $\begin{array}{l}0.8 \\
3\end{array}$ & A \\
\hline 8. & $\begin{array}{l}\text { Twitter motivate students to be more educationally } \\
\text { productive }\end{array}$ & $\begin{array}{l}3.2 \\
4\end{array}$ & 0.84 & A & $\begin{array}{l}3.0 \\
3\end{array}$ & $\begin{array}{l}0.9 \\
4\end{array}$ & A \\
\hline 9. & $\begin{array}{l}\text { Twitter online chat promotes someone to develop } \\
\text { critical thinking in his or her study }\end{array}$ & $\begin{array}{l}3.0 \\
9\end{array}$ & 1.03 & A & $\begin{array}{l}3.2 \\
5\end{array}$ & $\begin{array}{l}0.8 \\
7\end{array}$ & A \\
\hline 10. & $\begin{array}{l}\text { Facebook is a technological tool which nurtures the } \\
\text { student- teacher relationships }\end{array}$ & $\begin{array}{l}3.2 \\
6\end{array}$ & 0.87 & A & $\begin{array}{l}3.1 \\
4\end{array}$ & $\begin{array}{l}0.8 \\
7\end{array}$ & A \\
\hline 11. & $\begin{array}{l}\text { Facebook creates positive learning experiences for } \\
\text { learners }\end{array}$ & $\begin{array}{l}3.2 \\
9\end{array}$ & 0.88 & A & $\begin{array}{l}3.3 \\
1\end{array}$ & $\begin{array}{l}0.8 \\
0\end{array}$ & A \\
\hline 12. & Facebook updates me on current educational affairs & $\begin{array}{l}3.3 \\
0\end{array}$ & 0.82 & A & $\begin{array}{l}3.2 \\
7\end{array}$ & $\begin{array}{l}0.8 \\
3\end{array}$ & A \\
\hline 13. & $\begin{array}{l}\text { Facebook activity seduces me erotically which is } \\
\text { affecting my academic performance }\end{array}$ & $\begin{array}{l}3.2 \\
1\end{array}$ & 0.82 & A & $\begin{array}{l}3.2 \\
1\end{array}$ & $\begin{array}{l}0.8 \\
4\end{array}$ & A \\
\hline 14. & $\begin{array}{l}\text { Using twitter does not make me to feel outgoing on } \\
\text { issues regarding academics }\end{array}$ & $\begin{array}{l}3.1 \\
7\end{array}$ & 0.85 & A & $\begin{array}{l}3.1 \\
4\end{array}$ & $\begin{array}{l}0.8 \\
9\end{array}$ & A \\
\hline 15. & $\begin{array}{l}\text { Facebook motivates me to express my academic } \\
\text { problems }\end{array}$ & $\begin{array}{l}3.3 \\
3\end{array}$ & 0.79 & A & $\begin{array}{l}3.2 \\
3\end{array}$ & $\begin{array}{l}0.8 \\
3\end{array}$ & A \\
\hline 16. & $\begin{array}{l}\text { Twitter activity makes me feel less depressed each } \\
\text { time examination is approaching }\end{array}$ & $\begin{array}{l}3.1 \\
8\end{array}$ & 0.74 & A & $\begin{array}{l}3.1 \\
8\end{array}$ & $\begin{array}{l}0.7 \\
7\end{array}$ & A \\
\hline 17. & $\begin{array}{l}\text { Facebook helps me to connect with students who } \\
\text { share similar academic problem }\end{array}$ & $\begin{array}{l}3.2 \\
5\end{array}$ & 0.83 & A & $\begin{array}{l}3.1 \\
0\end{array}$ & $\begin{array}{l}0.9 \\
6\end{array}$ & A \\
\hline 18. & $\begin{array}{l}\text { Facebok help me to express my academic } \\
\text { challenges to my school counsellor privately } \\
\text { through the message feature }\end{array}$ & $\begin{array}{l}3.2 \\
2\end{array}$ & 0.75 & A & $\begin{array}{l}3.1 \\
7\end{array}$ & $\begin{array}{l}0.8 \\
3\end{array}$ & A \\
\hline 19. & $\begin{array}{l}\text { I am usually withdrawn from academic work due to } \\
\text { whatsapp addition }\end{array}$ & $\begin{array}{l}3.0 \\
8\end{array}$ & 0.80 & A & $\begin{array}{l}3.1 \\
3\end{array}$ & $\begin{array}{l}0.8 \\
0\end{array}$ & A \\
\hline 20. & $\begin{array}{l}\text { Twitter introduced me to an elevated risk of drug } \\
\text { use which is affecting my academic pursuit now. } \\
\text { Cluster Mean and Standard Deviation }\end{array}$ & $\begin{array}{l}3.9 \\
8 \\
2.1 \\
7\end{array}$ & 1.00 & A & $\begin{array}{l}3.1 \\
0 \\
\mathbf{3 . 1} \\
\mathbf{6} \\
\end{array}$ & $\begin{array}{l}0.9 \\
2 \\
\mathbf{0 . 4} \\
\mathbf{7} \\
\end{array}$ & A \\
\hline
\end{tabular}

Criterion Mean $(\bar{X})=2.50 ; \mathrm{SD}=$ Standard Deviation; $\mathrm{A}=$ Agree 
The result reveals that items 1 to 20 are within the range of 2.76 to 3.34 for both urban and rural areas which is more than the set benchmark mean of 2.50. The high mean score of 3.34 for item 5 indicated that social networking influence in-school adolescents to spend so much time on twitter and do nothing at all for hours, on academic work. In addition, the overall mean scores reveal that there is positive influence social networking on academic adjustment of rural and urban English Language students. Unlike urban area, mean scores indicating that social network influence students to develop vocabulary and create positive learning experience. This shows that respondents agree that social networking influences academic adjustment of urban and rural English Language students. Also the closeness of the overall standard deviation of both urban and rural English Language students shows that there is less disparity.

\section{Table 3. T- Test Analysis of the Mean Ratings of English Language Students from Urban and Rural Areas on the Influence Of Social Networking On Academic Adjustment}

\begin{tabular}{lllllllll}
\hline S/N & Location & $\mathbf{n}$ & $\bar{x}$ & SD & df & t & Sig.(2-tailed & Decision \\
\hline 1 & Rural & 121 & 3.17 & 0.45 & 605 & 0.21 & 0.83 & $\mathrm{Ho}_{3}$ \\
2 & Urban & 486 & 3.16 & 0.47 & & & & Accepted \\
\hline
\end{tabular}

The analysis of data in Table 3 shows that the probability associated with t-score value $(0.21)$ is 0.83 . And since the set probability level of 0.05 is less than the probability value associated, the null hypothesis is accepted. Therefore, there is no significant difference between the mean ratings of in-school adolescents from urban and rural areas on the influence of social networking on academic adjustment.

\section{Table 4. t- Test Analysis of the Mean Ratings of Male and Female English Language Students on the Influence of Social Networking On Academic Adjustment}

\begin{tabular}{lllllllll}
\hline S/N & Gender & n & $\bar{x}$ & SD & df & t & Sig.(2-tailed & Decision \\
\hline 1 & Male & 267 & 3.17 & 0.47 & 605 & 0.41 & 0.68 & $\mathrm{Ho}_{4}$ \\
2 & Female & 340 & 3.15 & 0.47 & & & & Accepted
\end{tabular}

The t- test data analysis in Table 4 reveals that calculated t value $(0.41)$ is significant at probability level of 0.68 . Since the associated probability is greater than the set probability level, the null hypothesis is accepted. The closeness of male and female students' mean scores further shows that the influence of social networking on the students' academic adjustment does not differ significantly. Implicitly, there is no significant difference between the mean ratings of male and female English Language students on the influence of social networking on academic adjustment.

\section{Discussion}

The finding revealed that social networking influences male and female English Language students' academic adjustment. The positive influence include easy communication, academic peer-review, vocabulary development, motivates students for better learning, motivate students to be more educationally productive, nurtures studentteacher relationships, and positive learning experiences for learners. Others include students are updated on current educational affairs, motivates students to express academic problems, share similar academic problem, and to express academic challenges to school counsellor privately. This is in line with Osa-Edoh and lyamu (2012) who 
showed that social life adjustment influences male and female students academic positively. This finding is very interesting because students acquire social competences through social networking. No wonder, some adults engage in social media such as facebook, twitter, 2go, blog and email. In addition, it was found that there are some negative influences of social networking on male and female English Language students. These include low academic grade, vulnerable to examination malpractice, spend very much time on twitter, erotic seduction, withdrawal from academic work, and elevated risk of drug use. This further collaborates with Akaneme, Ibenegbu and Nwosu (2013) who found that students' involvement in social networking has a harmful impact on their academic success.

The result of the null hypothesis indicated that there is no significant difference between the mean ratings of in-school adolescents from urban and rural areas on the influence of social networking academic adjustment. This is not in consonance with Paramanik, Saha, and Mondal (2014) who indicated that there was significant difference between the secondary school students on the basis of location. This finding is not unexpected because of the recent increase in social networking among adolescents in both urban and rural areas. However, it shows that both urban and rural adolescents are likely to be exposed either the positive or negative influence of social networking.

The result indicated that social networking influences academic adjustment of urban and rural English Language students. The positive influence include easy communication, academic peer-review, vocabulary development, motivates students for better learning, motivate students to be more educationally productive, nurtures student-teacher relationships, and positive learning experiences for learners. Others include students are updated on current educational affairs, motivates students to express academic problems, share similar academic problem, and to express academic challenges to school counsellor privately. This finding concurs with Chen, Li and Rubin (1997) who indicated that academic achievement was associated with social functioning and adjustment in Chinese children. This finding is very interesting as both urban and rural in-school adolescents seem to be developing vocabulary and interpersonal relationship with their teachers and school counselors through social networking. It is astonishing since the adolescents use the platform to assert and express their academic problems. While the negative influence of social networking on male and female in-school adolescents include low academic grade, vulnerable to examination malpractice, spend very much time on twitter, erotic seduction, withdrawal from academic work, and elevated risk of drug use. This agrees with the study of Ojo and Omoyemju (2008) on relationship between internet addiction and academic locus of control of students in selected universities in Nigeria. It was also revealed that there is no significant difference between the mean ratings of male and female English Language students on the influence of social networking on academic adjustment. This finding disagrees with Paramanik, Saha, and Mondal (2014) who indicated that there was significant difference between the students on the basis of location. It is not surprising that social networking influence academic adjustment of urban and rural English Language students because most their activities are seem to be embedded on internet resources. They usually engage in internet surfing probably because it helps them to develop vocabulary and interpersonal relationship. Since the social networking resources helps urban and rural students to communicate easily, do academic peer-review, develop vocabulary, motivate students to be more educationally productive, nurtures student-teacher relationships, and enhances positive learning experiences among learners, it implies that both urban and rural English Language students' academic adjustment will be encouraging. But if the influence of social networking is negative, it implies that both urban and rural English Language students may be destructive in terms of outdoor activities and they will not adjust very well in school. 


\section{Conclusions}

Based on the findings and discussions, it concluded that there is positive influence of social networking on male and female in-school adolescents' academic adjustment. The result concluded that there is positive influence of social networking on academic adjustment of urban and rural in-school adolescents. It was also concluded that there is no significant difference between the mean ratings of in-school adolescents from urban and rural areas on the influence of social networking academic adjustment. It was also concluded that there is no significant difference between the mean ratings of male and female in-school adolescents on the influence of social networking on academic adjustment.

\section{Limitations of the Study}

In the course of carrying out this study, we encountered challenge which includes:

(a) In some schools, the gender mix was distorted in favour of the boys, therefore, the gender in the sampling was affected.

\section{References}

[1] I. N. Akaneme, C. I. Ibenegbu and E. N. Nwosu, "Adolescents and use of social networking sites", Golden Research Thought-International Multidisciplinary Research Journal, vol. 3, no. 5), (2013), pp. 15

[2] A. Awad, "Facebook impact on psychological and social adjustment of deaf high school students in Jordan", Journal of Education and Practice, vol. 4, no. 3, (2013), pp. 57-69.

[3] Awake, "What Should I know social networking?", Part 1, pp. 24.25.

[4] M. D. Back, J. M. Stopfer. S. Vazire, S. Gaddis, S. C. Schmukle, B. Eglott and S. D. Gosling, "Facebook Profiles reflect actual personality, not self- idealization", Psychological Science, 2, 2011, July, (2010), pp. 372-374.

[5] R. K. Baker and K. M. White, "Predicting adolescent' use of social networking sites from an extended theory of planned behaviour perspective", Computers in Human Behaviour, vol. 26, (2010), pp. 15911597.

[6] A. Bandura, "Social foundations of thought and action", Upper Saddle River, NJ: Prentice Hall, (1986).

[7] T. E. Bosch, "Using online social networking for teaching and learning: Facebook use at the University of Cape Town", Communicatio, vol. 35, no. 2, (2009), pp. 185-200.

[8] D. M. Boyd and N. B. Ellison, "Social network sites definition, history and scholarship", Journal of computer- medicated communication, vol. 13, no. 1, (2007), pp. 210-230.

[9] F. S. Chen, Y. M. Lin and C. A. Tu, "A study of the emotional intelligence and life adjustment of senior high school students", World Transactions on Engineering and Technology Education, vol.5, no. 3, (2006), pp. 473-476.

[10] N. B. Ellison, C. Stemfield and C. Lampe, "The benefits of facebook "friends"”, Social capital and College Students' use of Online Social Networking Sites Journal of Computer-Mediated Communication, vol. 12, (2007), pp. 1143-1168.

[11] O. Eren, "Student attitude towards using social networking in foreign language classes, a facebook example", International Journal Of Business And Social Science, vol. 3, no. 20, (2012), pp. 23-35.

[12] W. Grabe and R. B. Kaplan, "Theory and practice of writing: An applied linguistic perspective", Longman, New York, (1996).

[13] N.M. Idankwo, "The use of social media among Nigerian youths", www.slideshare.net/goldlami/theuse-of-social-media-networks-among-nigerianyouths, (2011).

[14] G. Kao and M. Tienda, "Educational aspirations of minority youth", American Journal of Education, vol. 106 , no. $3,3,(\mathbf{1 9 9 8})$, pp. 49-384.

[15] W. F. Kumuyi, "3 ways social media benefits church leaders", Retrieved from http://www.christianitytoday.com/edstetzer/2015/february/3-ways-social-media-benefits-churchleaders.html, (2015).

[16] D. J. Kuss and M. D. Griffiths, "Online social networking and addiction-a review of the psychological literature", International Journal of Environmental Research and Public Health, vol. 8, no. 9, (2011), pp. 3528-3552.

[17] A. Lenhart, K. Purcell, A. Smith and K. Zickuhr, "Social media and mobile internet use among teens and young adults", Retrieved from http://www.pewintement.org/Reports/2010/Social-media-and-youngAdults.aspx, (2010).

[18] R. Mason, "Learning technologies for adult continuing education", Studies in Continuing Education, vol. 28, (2006), pp. 121-133. 
[19] M. Miah, A. Omar and M. Golding, "Effects of social networking on adolescent education", proceeding of information systems educators conference. New Orleans Lausiana, U.S.A, (2012).

[20] C. Moreno, J. Egan, Y.,Ox and Ba1ckers, (2011).

[21] A. S. Musa, "Social media in the learning process of Nigerian students of mass communication", New Media and Mass Communication, vol. 44, (2015), pp. 25-30.

[22] O. O. Ojo and M. A. Omoyemiju, "Relationship between internet addiction and academic locus of control of students in a selected University in Nigeria", Counselling Implications, (2008).

[23] C. O. Omekwu, H. N. Ekeand and N. J. Odoh, "The use of social networking sites among the undergraduate students of University of Nigeria", Nsukka, (2014).

[24] G.I. Osa-Edoh and F.I Iyamu, "Social life adjustment and academic achievement of adolescents in Edo State: implication for counseling", Ozean Journal of Applied Sciences, vol. 5, no. 2, (2012), pp. 159167.

[25] J. S. Phinney, G. Horenczyk, K. Liebkind and P. Vedder, "Ethnic identity, immigration, and well- being: an international perspective", Journal of Social Issues vol. 57, no. 3, (2001), pp. 493-510.

[26] J. Paramanik, B. Saha and B. C. Mondal, "Adjustment of secondary school students with respect to gender and residence", American Journal of Educational Research, vol. 2, no. 12, (2014), pp. 11381143.

[27] I. Sani and M. S. Bature, "The impact of social networks on ESL undergraduate students' writing in Nigeria”, Arts Social Science Journal, vol. 5, (2014), p. 69.

[28] K. Subbrahmanyam and P. Greenfield, "Online communication and adolescent", Future Child, vol. 18, no. 1, (2008), pp. 119-46.

[29] M. F. Wright and Y. Li, "The associations between young adults' face-to-face prosocial behaviors and their online prosocial behaviors", Computers in Human Behavior, vol. 27, no. 5, (2011), pp. 1959-1962.

[30] S. Zhao, S. Grasmuck and J. Martin, "Identity construction on facebook: digital empowerment in anchored relationships", Computers in Human Behavior, vol. 24, (2008), pp. 1816-1836.

[31] S. Ziegler, The (mis)education of Generation M. Learning. Media and Technology, 32 (1), (2007). 6981. 